\title{
GMR
}

\section{Relationship between TLR4 and MCP2 expression levels and habitual abortion}

\author{
X.P. Li ${ }^{1}$, L.N. Song ${ }^{2}$, L.P. Tian ${ }^{3}$ and Y.S. Zhang ${ }^{1}$ \\ ${ }^{1}$ Department of Obstetrics, Jinnan Maternity and Child Care Hospital, \\ Jinnan, Shandong, China \\ ${ }^{2}$ Department of Internal Medicine, Jinnan Maternity and Child Care Hospital, \\ Jinnan, Shandong, China \\ ${ }^{3}$ Department of New Screening Center, Jinnan Maternity and Child Care Hospital, \\ Jinnan, Shandong, China \\ Corresponding author: Y.S. Zhang \\ E-mail: njshfieh5522@163.com
}

Genet. Mol. Res. 15 (2): gmr. 15027378

Received October 13, 2015

Accepted December 8, 2015

Published April 25, 2016

DOI http://dx.doi.org/10.4238/gmr.15027378

\begin{abstract}
Habitual abortion is associated with the altered expression of multiple genes. This study was carried out to investigate the relationship between expression of Toll-like receptor 4 (TLR4) and monocyte chemotactic protein 2 (MCP2 or CCL8) and habitual abortion. This was done by detecting and comparing their relative expression in peripheral blood and placental villi of patients and healthy fertile women. Based on our previous research, 85 subjects with habitual abortion (study group) and 40 healthy fertile women (control group), who were admitted to our hospital between June 2013 and December 2014, were enrolled in this study. After these subjects signed written informed consent, peripheral blood samples and villous tissues were collected, from which the total RNA was extracted. The expression of TLR4 and MCP2 was detected with quantitative reverse transcription-polymerase chain reaction, using GAPDH as a reference control. The expression of TLR4 and MCP2 in the peripheral blood and villous tissues of the study group was significantly higher than that of the control group $(\mathrm{P}<0.05)$. A positive correlation was also
\end{abstract}


observed between the changes in expression levels of TLR4 and $\mathrm{MCP} 2$. In conclusion, TLR4 and MCP2 expression correlated with the occurrence of habitual abortion. Detecting expression changes in TLR4 and MCP2 in the peripheral blood is a feasible method for predicting the occurrence of abortion in women of child-bearing age.

Key words: Habitual abortion; TLR4; MCP2; Gene expression

\section{INTRODUCTION}

Habitual abortion, also known as recurrent miscarriage, is an infertility disease clinically defined as 2 to 3 consecutive failed pregnancies or stillbirth. It is a common disease in women of child-bearing age and most patients suffer from varying degrees of depression (Burrough et al., 2011; Chessa et al., 2014). This disease seriously affects the physical and mental health of patients, and even influences their normal lives.

The pathogenesis of habitual abortion has not yet been identified. It is acknowledged that the causes of habitual abortion are multiple and complex, including genetic factors, immunological factors, trauma, and viral/bacterial infection (Clark et al., 2003). With the development of laboratory medicine and gene engineering, some progress has been made to explore the relationship between gene expression and habitual abortion occurrence. It has been found that habitual abortion is correlated with expression of Toll-like receptor 2 (TLR2), nuclear factor (NF)$\kappa \mathrm{B}$, methylenetetrahydrofolate reductase, and human leukocyte antigen. This provides a clinical basis for forecasting the occurrence of habitual abortion (Jiang et al., 2006; Heinig et al., 2007; Hirschfeld et al., 2007; Gulic et al., 2013). Therefore, understanding the pathogenesis correctly is essential for discovering potential effective methods of prevention and treatment, with the final aim of reducing the incidence of habitual abortion and improving the diagnosis and treatment standards.

Studies have found that TLRs have a direct relationship with habitual abortion due to their promoter polymorphisms, and monocyte chemotactic protein 2 (MCP2) has a potential phenotypic correlation with habitual abortion. In-depth understanding of the pathogenesis of habitual abortion may help explore effective clinical markers and provide theoretical support for clinical diagnosis, which can effectively reduce its incidence and adverse effects (Clark et al., 2003; Silva et al., 2012; Li et al., 2013; Rashidi et al., 2015). Combined with our former research, 85 subjects with habitual abortion (study group) and 40 healthy fertile women (control group), who were admitted to our hospital between June 2013 and December 2014, were enrolled in this study. After these subjects signed written informed consent, peripheral blood samples and villous tissues were collected, from which the total RNA was extracted. The expression of TLR4 and MCP2 was detected with quantitative reverse transcriptionpolymerase chain reaction (qRT-PCR) to investigate the correlation between changes in expression and the occurrence of habitual abortion. In this way, we hope to provide more information for further study of the pathogenesis of habitual abortion.

\section{MATERIAL AND METHODS}

\section{Clinical data}

Eighty-five patients (average age $30.7 \pm 4.6$ years) with habitual abortion admitted to 
our hospital from December 2013 to June 2014 were enrolled in the study group. They had been diagnosed with miscarriage at least twice with the assistance of ultrasonic confirmation. Their chromosome examination results, endocrine function and uterine were normal. Forty normal fertile women (average age $31.1 \pm 4.5$ years) without abortion history or family genetic disease who were referred to the hospital during the same period were enrolled in the control group. The average ages of the two groups had no statistical difference $(\mathrm{P}>0.05)$. All subjects were informed of the study and signed the informed consent form.

The blood collection tools and anticoagulant tubes used in the study were provided by our department. RNA extraction TRIzol kits and reverse transcription kits were bought from Takara Bio Group (Shiga, Japan); qRT-PCR kits were from Promega Corporation (USA); PCR primers were synthesized by Shanghai Yingjun Company (Shanghai, China); and the PCR instrument used was BIO-IQ5 (Bio-Rad Laboratories Inc., USA).

\section{Sample collection and RNA extraction}

Venous blood (3-5 mL) was drawn from subjects who met all criteria, and the chorionic villi were obtained through suction operation and immediately frozen in liquid nitrogen. RNA was extracted from the whole blood and the equal-weight chorionic villi by TRIzol. Briefly, $1 \mathrm{~mL}$ TRIzol reagent was added to $1 \mathrm{~mL}$ blood or $50 \mathrm{~mL}$ villi tissue, which was then homogenized on ice and put back into the original centrifuge tube. Chloroform $(0.2$ $\mathrm{mL}$ for blood/ $0.16 \mathrm{~mL}$ for villi) was added and tubes were oscillated rapidly for $15 \mathrm{~s}$ and then left to stand for $2 \mathrm{~min}$. Tubes were centrifuged at $4^{\circ} \mathrm{C}$ and $12,000 \mathrm{~g}$ for $15 \mathrm{~min}$, after which the supernatants were placed into new $1.5-\mathrm{mL}$ RNase-free tubes. Isopropyl alcohol $(0.5 \mathrm{~mL})$ was added to each tube, mixed gently, and placed at $-20^{\circ} \mathrm{C}$ for $2 \mathrm{~h}$. After this, the tubes were centrifuged at $4^{\circ} \mathrm{C}$ and $12,000 \mathrm{~g}$ for $15 \mathrm{~min}$ and the supernatants were discarded. The pellets were washed with $75 \%$ ethanol, after which the tubes were centrifuged at $4{ }^{\circ} \mathrm{C}$ and $7500 \mathrm{~g}$ for $5 \mathrm{~min}$, and the supernatant was discarded. The tubes were kept at room temperature for $10 \mathrm{~min}$ and $20 \mu \mathrm{L}$ ultra-pure water was added to the pellet (to promote the dissolution of the pellet, the tubes were incubated at $65^{\circ} \mathrm{C}$ for $10-15 \mathrm{~min}$ ). The extracted RNA was analyzed by modified gel electrophoresis, and then aliquoted into $0.5-\mathrm{mL}$ tubes. Ten microliters of RNA extract was removed from each tube and diluted in $490 \mu \mathrm{L} \mathrm{ddH}_{2} \mathrm{O}$ (50 times dilution). The concentrations $(\mathrm{mg} / \mathrm{mL})$ were detected on an ultraviolet spectrophotometer.

\section{cDNA template synthesis}

After the quantification of the extracted RNA, $1 \mu \mathrm{g}$ RNA was used to conduct reverse transcription. The extracted RNA was reversely transcribed into cDNA with reverse transcription kits according to the manufacturer protocol. Briefly, the RNA-primer mixture was made in a tube and then mixed with $1 \mu \mathrm{g}$ RNA template, $0.5 \mu \mathrm{L}$ random primer and 0.5 $\mu \mathrm{L}$ oligo (DT) primer. RNase-free water was then added to $5 \mu \mathrm{L}$ and the mixture was placed in a $70^{\circ} \mathrm{C}$ water bath for $15 \mathrm{~min}$. The mixture was cooled on ice for $5 \mathrm{~min}$ and spun briefly for $5 \mathrm{~min}$. The reverse transcription reaction solution was prepared according to the manufacturer protocol. This reaction solution was combined with the RNA-primer mixture to conduct PCR reverse transcription. The protocol used was $42^{\circ} \mathrm{C}$ for $1 \mathrm{~h}$ and $70^{\circ} \mathrm{C}$ for $15 \mathrm{~min}$. The products were stored at $4^{\circ} \mathrm{C}$. The reverse transcription product was stored at $-80^{\circ} \mathrm{C}$. 


\section{Detection of TLR4 and MCP2 expression in peripheral blood and villi tissue by qRT-PCR}

The reverse transcribed cDNA was the template for detection. The reaction system included $8 \mu \mathrm{L} 2 \mathrm{X}$ Buffer MIX, $0.5 \mu \mathrm{L}$ each primer (forward and reverse), $1 \mu \mathrm{L} \mathrm{cDNA}$, and $10.5 \mu \mathrm{L} \mathrm{ddH}_{2} \mathrm{O}$. GAPDH was used as an internal control. Each sample was repeated three times. The reaction was conducted for 50 cycles of $94^{\circ} \mathrm{C}$ for $2 \mathrm{~min} ; 94^{\circ} \mathrm{C}$ for $15 \mathrm{~s}$; and $60^{\circ} \mathrm{C}$ for $45 \mathrm{~s}$. Expression of TLR4 and MCP2 was evaluated by fold-changes normalized to GAPDH. Primers for TLR4, MCP2 and GAPDH were designed by the Primer 5 software according to the published gene sequences in NCBI. Primer sequences are shown in Table 1.

Table 1. Primer sequences.

\begin{tabular}{l|l}
\hline Name & Sequence $\left(5^{\prime}-3^{\prime}\right)$ \\
\hline TLR4 $\mathrm{F}$ & TTCCTGCAATGGATCAAG \\
\hline TLR4 R & CCTGCTTATCTGAAGGTGT \\
\hline MCP2 $\mathrm{F}$ & AGCAGCAAGCAACTACGA \\
\hline MCP2 R & TCTTAGGCTGAGGAGGT \\
\hline GAPDH F & ACCCCTTCATTGACCTC \\
\hline GAPDH R & CTTCACCACCTTCTTGAT \\
\hline
\end{tabular}

\section{Statistical analysis}

The data from qRT-PCR were analyzed by SPSS17.1 (Chicago, IL, USA). The expression quantities of TLR4 and MCP2 are reported as means \pm standard deviation. The difference in TLR4 and MCP2 expression between the two groups was compared, and $\mathrm{P} \leq 0.05$ indicating statistical significance.

\section{RESULTS}

\section{Gel electrophoresis detection of extracted RNA}

Extracted RNA was confirmed by running gel electrophoresis to ensure that the extraction was as expected and usable for the following study. The results are shown in Figure 1 (due to the large number of samples only a few samples are shown) and all indicated that the extracted RNA samples could be used for the following study.

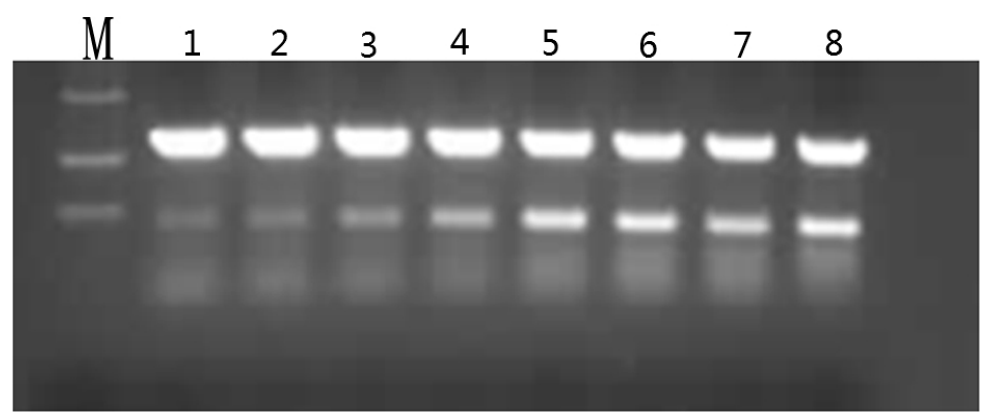

Figure 1. Results of RNA sample detection. Lane $M=$ RNA molecular weight marker; lanes 1-6= partial sample results. 


\section{Analysis of TLR4 and MCP2 expression in the study and control groups}

Results from qRT-PCR showed that the expression levels of TLR4 and MCP2 in the study group were significantly higher than in the control group (Table 2). In patients with habitual abortion, the expression levels of TLR4 and MCP2 were significantly higher than those in the control group. The results also show that the change in TLR4 expression was close to that of MPC2, which indicates that the expression of MCP2 and TLR4 is positively correlated and could be useful values in the pathogenesis and diagnosis of habitual abortion.

Table 2. Expression changes of TLR4 and MCP2 (means $\pm \mathrm{SD}$ in pg/mL).
\begin{tabular}{l|c|c}
\hline Group & TLR4 expression & MCP2 expression \\
\hline Study group & $48.97 \pm 5.68$ & $50.12 \pm 3.56$ \\
\hline Control group & $14.78 \pm 4.32$ & $17.64 \pm 4.03$ \\
\hline P value & 0.0138 & 0.035 \\
\hline
\end{tabular}

\section{DISCUSSION}

The birth of a new life is an extremely complex and regulated process, and involves the immunological interactions between maternal and paternal gametes, the maternal immunological function, expression of genes inherited from both parents, and chromosome structure (Wilding et al., 2004; Burrough et al., 2011; Turner et al., 2012; Xie et al., 2014). At present, habitual abortion not only seriously affects the patient's psychological and physiological health, but the quality of life of the patient's family. In addition, varying degrees of depression have been found to occur in the majority of patients. Studies have found that the probability of depression was significantly higher in patients with habitual abortion than that in normal pregnant women (Burrough et al., 2011; Yin et al., 2013; Chessa et al., 2014).

Studies have shown that the causes of habitual abortion can be divided into two major categories: immune factors and non-immune factors. Immune factors mainly refer to autoimmune disorders and impaired self-regulation of hormones, resulting in recurrent miscarriage (Yu et al., 2008; Andre and Cortes, 2015; Chen, 2015). In this study, the focus lies on MCP2 (CCL8), an immune chemokine that has some connection with the regulation of the human immune system. Research has found that the expression of MCP2 and its receptors is involved in the erosion of trophoblast cells and the activation and migration of immune cells, which plays an important role in inducing pregnancy immune tolerance. The expressed and secreted regulatory proteins play an important role in the immune tolerance in pregnancy ( $\mathrm{Li}$ et al., 2013; Garcia et al., 2015; Rashidi et al., 2015). The abnormal expression of MCP2 will directly lead to embryonic diapauses or might affect the embryo implantation and growth, indirectly causing abortion. Therefore, the study of the changes in expression of MCP2 has important significance in illustrating the pathogenesis of habitual abortion (Park et al., 2014; Pérez-Garijo and Steller, 2014; Hsuuw and Chan, 2015; Jung et al., 2015). TLR4 is one of the important human innate immune receptors. It can induce the activation of the NF- $\mathrm{BB}$ transcription factor through the recognition of lipopolysaccharides and regulate the expression of related factors, such as tumor necrosis factor (TNF)- $\alpha$ and interleukin (IL)-12, all of which can lead to habitual abortion.

The results of this study show that TLR4 and MCP2 expression in the peripheral blood and chorionic villi of patients with habitual abortion was significantly higher than that 
in normal pregnant women, which is consistent with previous studies. This indicates that TLR4 and MCP2 play an important role in the occurrence of habitual abortion. However, the relationship between the changes in expression of TLR4 and MCP2 and the incidence of habitual abortion is not well studied thus far. It has been suggested that a relationship exists and our study shows that there is a positive correlation between TLR4 expression, MCP2 expression and occurrence of habitual abortion. Detection of TLR4 and MPC2 can effectively predict the probability of habitual abortion in the clinic, which could enable clinicians to take action as soon as possible and to avoid the adverse consequences.

\section{Conflicts of interest}

The authors declare no conflict of interest.

\section{ACKNOWLEDGMENTS}

We thank the anonymous reviewers for reviewing this manuscript.

\section{REFERENCES}

Andre F and Cortes J (2015). Rationale for targeting fibroblast growth factor receptor signaling in breast cancer. Breast Cancer Res. Treat. 150: 1-8. http://dx.doi.org/10.1007/s10549-015-3301-y

Burrough ER, DiVerde KD, Sahin O, Plummer PJ, et al. (2011). Expression of toll-like receptors 2 and 4 in subplacental trophoblasts from guinea pigs (Cavia porcellus) following infection with Campylobacter jejuni. Vet. Pathol. 48: 381 388. http://dx.doi.org/10.1177/0300985810375809

Chen J (2015). Cardiac toxicity by sublethal 2,3,7,8-tetrachlorodibenzo-p-dioxin correlates with its anti-proliferation effect on cardiomyocytes in zebrafish embryos. Environ. Toxicol. Chem. 34: 420-428. http://dx.doi.org/10.1002/etc.2822

Chessa D, Spiga L, De Riu N, Delaconi P, et al. (2014). Lipopolysaccharides belonging to different Salmonella serovars are differentially capable of activating Toll-like receptor 4. Infect. Immun. 82: 4553-4562. http://dx.doi.org/10.1128/ IAI.02297-14

Clark DA, Yu G, Arck PC, Levy GA, et al. (2003). MD-1 is a critical part of the mechanism causing Th1-cytokinetriggered murine fetal loss syndrome. Am. J. Reprod. Immunol. 49: 297-307. http://dx.doi.org/10.1034/j.1600$\underline{0897.2003 .00045 . \mathrm{x}}$

Garcia SM, Marinho LS2, Lunardelli PA2, Seneda MM, et al. (2015). Developmental block and programmed cell death in Bos indicus embryos: effects of protein supplementation source and developmental kinetics. PLoS One 10: e0119463. http://dx.doi.org/10.1371/journal.pone. 0119463

Gulic T, Laskarin G, Redzovic A, Eminović S, et al. (2013). The significance of heat-shock protein gp96 and its receptors' CD91 and Toll-like receptor 4 expression at the maternal foetal interface. Am. J. Reprod. Immunol. 70: 10-23. http:// dx.doi.org/10.1111/aji.12096

Heinig J, Steinhard J, Schmitz R, Nofer JR, et al. (2007). Maternal serum free $\beta$-hCG and PAPP-A in patients with habitual abortion-influence on first-trimester screening for chromosomal abnormalities. Prenat. Diagn. 27: 814-816. http:// dx.doi.org/10.1002/pd.1779

Hirschfeld AF, Jiang R, Robinson WP, McFadden DE, et al. (2007). Toll-like receptor 4 polymorphisms and idiopathic chromosomally normal miscarriage. Hum. Reprod. 22: 440-443. http://dx.doi.org/10.1093/humrep/del377

Hsuuw YD and Chan WH (2015). Apoptotic effects of dillapiole on maturation of mouse oocytes, fertilization and fetal development. Drug Chem. Toxicol. 38: 469-476. http://dx.doi.org/10.3109/01480545.2014.1002037

Jiang WL, Liu Z, Yang ZQ, Xu SX, et al. (2006). Investigation of viral pathogens contributing to habitual abortion. Nan Fang Yi Ke Da Xue Xue Bao 26: 1020-1022.

Jung EM, Choi YU, Kang HS, Yang H, et al. (2015). Evaluation of developmental toxicity using undifferentiated human embryonic stem cells. J. Appl. Toxicol. 35: 205-218. http://dx.doi.org/10.1002/jat.3010

Li Y, Zhong S and Yao R (2013). Influence of LPS and Toll-like receptor 4 antagonist on progesterone receptor, interleukin$1 \beta$, and cyclooxygenase-2 in decidual cells. Zhong Nan Da Xuе Xие Bao Yi Xue Ban 38: 162-168. 
Park SH, Cho HS and Yu IJ (2014). Effect of bovine follicular fluid on reactive oxygen species and glutathione in oocytes, apoptosis and apoptosis-related gene expression of in vitro-produced blastocysts. Reprod. Domest. Anim. 49: 370377. http://dx.doi.org/10.1111/rda.12281

Pérez-Garijo A and Steller H (2014). The benefits of aging: cellular senescence in normal development. EMBO J. 33: 99100. http://dx.doi.org/10.1002/embj.201387401

Rashidi N, Mirahmadian M, Jeddi-Tehrani M, Rezania S, et al. (2015). Lipopolysaccharide- and lipoteichoic acidmediated pro-inflammatory cytokine production and modulation of TLR2, TLR4 and MyD88 expression in human endometrial cells. J. Reprod. Infertil. 16: 72-81.

Silva AP, Costa EA, Macêdo AA, Martins Tda M, et al. (2012). Transcription of pattern recognition receptors and abortive agents induced chemokines in the bovine pregnant uterus. Vet. Immunol. Immunopathol. 145: 248-256. http://dx.doi. org/10.1016/j.vetimm.2011.11.007

Turner ML, Healey GD and Sheldon IM (2012). Immunity and inflammation in the uterus. Reprod. Domest. Anim. 47: 402-409. http://dx.doi.org/10.1111/j.1439-0531.2012.02104.x

Wilding M, Forman R, Hogewind G, Di Matteo L, et al. (2004). Preimplantation genetic diagnosis for the treatment of failed in vitro fertilization-embryo transfer and habitual abortion. Fertil. Steril. 81: 1302-1307. http://dx.doi. org/10.1016/j.fertnstert.2003.10.028

Xie H, Sheng L, Zhou H and Yan J (2014). The role of TLR4 in pathophysiology of antiphospholipid syndrome-associated thrombosis and pregnancy morbidity. Br. J. Haematol. 164: 165-176. http://dx.doi.org/10.1111/bjh.12587

Yin T, Huang F, Ren J, Liu W, et al. (2013). Bilateral sudden hearing loss following habitual abortion: a case report and review of literature. Int. J. Clin. Exp. Med. 6: 720-723.

Yu G, Sun Y, Foerster K, Manuel J, et al. (2008). LPS-induced murine abortions require C5 but not C3, and are prevented by upregulating expression of the CD200 tolerance signaling molecule. Am. J. Reprod. Immunol. 60: 135-140. http:// dx.doi.org/10.1111/j.1600-0897.2008.00605.x 